\title{
Expression of Bottom Component RNA of Cowpea Mosaic Virus in Cowpea Protoplasts
}

\author{
GEERTJE REZELMAN, ROB GOLDBACH,* AND ALBERT VAN KAMMEN \\ Department of Molecular Biology, Agricultural University, 6703 BC Wageningen, The Netherlands
}

\begin{abstract}
Upon inoculation of cowpea protoplasts with the bottom component of cowpea mosaic virus, at least six virus-induced proteins (with sizes of 170, 110, 87, 84, 60, and 32 kilodaltons) are synthesized, but not the capsid proteins (37 and 23 kilodaltons). These bottom-component-induced proteins were studied with respect to their genetic origin and mode of synthesis. The analyses were based on their electrophoretic peptide patterns resulting from partial digestion with Staphylococcus aureus protease V8. Comparison of the peptide patterns of the virusinduced proteins with those of the cowpea mosaic virus RNA-coded polypeptides produced in rabbit reticulocyte lysate showed that the 170- and 32-kilodalton polypeptides, which are the first viral products in cowpea mosaic virus-infected cells, were actually coded by the bottom component RNA of the virus. The $110-, 87-$, and 84-kilodalton polypeptides, and possibly the 60-kilodalton polypeptide, appeared to have amino acid sequences in common with the 170-kilodalton polypeptide, demonstrating that they were virus coded as well. The results indicated that cowpea mosaic virus bottom component RNA was translated in vivo into a single 200 -kilodalton polyprotein from which probably all bottomcomponent-specific proteins arose by three successive cleavages.
\end{abstract}

The single-stranded RNA genome of cowpea mosaic virus (CPMV), type member of the comovirus group, is divided between two separate (bottom [B] and middle [M]) nucleoprotein particles $(1,10,19)$. Both $B$ and $M$ particles are necessary for virus multiplication $(5,18)$, indicating that the genetic information is distributed between both $B$ and $M$ RNAs (molecular weights, respectively: $2.02 \times 10^{6}$ and $1.37 \times 10^{6}$ [14]). The RNAs both possess $3^{\prime}$-terminal polyadenylate tails (7) and single proteins covalently attached to their $5^{\prime}$ termini $(3,16)$. Little is known about the location of genes on both RNAs. Infection of cowpea mesophyll protoplasts with the natural mixture of CPMV components results in the synthesis of at least eight virus-induced polypeptides, of $170,110,87,84$, $68,37,30$, and 23 kilodaltons, the 37-kilodalton (37K) and $23 \mathrm{~K}$ polypeptides representing the capsid proteins (15). Moreover, $130 \mathrm{~K}$ and $112 \mathrm{~K}$ polypeptides are sometimes found in very small amounts (P. J. M. Rottier, G. Rezelman, and A. van Kammen, J. Gen. Virol., in press). We have previously shown (8a) that in cowpea protoplasts the B RNA can be replicated and expressed independently, i.e., in the absence of $M$ component. Upon inoculation of protoplasts with the CPMV B component alone, at least the $170 \mathrm{~K}, 110 \mathrm{~K}, 87 \mathrm{~K}, 84 \mathrm{~K}$, and $30 \mathrm{~K}$ virus-specific polypeptides are synthesized, but not the coat proteins. It has therefore been proposed that B
RNA encodes the early functions (e.g., the replicase) and that M RNA encodes the late functions (e.g., the coat proteins) during viral infection (8a). As the B RNA has only a coding capacity for polypeptides totaling approximately 250 kilodaltons, the question arises, however, of whether all B-component-induced polypeptides are actually virus coded and how B RNA is translated. To study this we have compared the peptide maps (2) from the virus-induced polypeptides formed in CPMV-infected protoplasts and from the B-RNA-coded polypeptides produced in the rabbit reticulocyte system. The results indicate that $B$ RNA is translated in vivo into one large polyprotein from which probably all B-RNA-specific proteins arise by three posttranslational cleavages.

\section{MATERIALS AND METHODS}

Virus purification and separation of $M$ and $B$ components. CPMV (yellow strain) was grown in Vigna unguiculata L. (Blackeye Early Ramshorn) and purified as previously described $(11,17)$. The $B$ and $M$ virion components were separated by three cycles of centrifugation in a linear 15 to $30 \%$ zonal sucrose gradient (Beckman Ti 15 rotor, $16 \mathrm{~h}, 23,000$ rpm at $10^{\circ} \mathrm{C}$ ). By means of the local lesion infectivity assay (9) it was determined that $M$ components were free of $B$ and that $B$ components contained less than $0.2 \% \mathrm{M}$

Preparation of CPMV RNA. CPMV RNAs were extracted from separated components as described by 
Davies et al. (4). Purity and quality of isolated RNAs were tested by electrophoresis in a $1 \%$ agarose gel (8).

Preparation of cowpea protoplasts and inoculation with CPMV. Cowpea mesophyll protoplasts were isolated as previously described in detail $(9,15)$ and inoculated by resuspension at a concentration of $5 \times 10^{5}$ protoplasts per $\mathrm{ml}$ in $0.6 \mathrm{M}$ mannitol-0.01 M potassium citrate, $\mathrm{pH} 5.2$, containing $7 \mu \mathrm{g}$ of $\mathrm{B}$ component per $\mathrm{ml}$ or $14 \mu \mathrm{g}$ of a 1:1 (wt/wt) mixture of $B$ and $M$ components per $\mathrm{ml}$. The suspension was incubated for $15 \mathrm{~min}$ at room temperature. Protoplasts were then collected by centrifugation for $2 \mathrm{~min}$ at 600 $\times g$ and washed three times with $0.6 \mathrm{M}$ mannitol-10 $\mathrm{mM} \mathrm{CaCl}$.

Incubation of protoplasts and labeling of proteins. Washed protoplasts were incubated at a concentration of $5 \times 10^{5}$ cells per ml in culture medium as previously described in detail (15). Neither actinomycin D nor any other inhibitor of host protein synthesis was added. For labeling of proteins, 5-ml portions of protoplasts were labeled with $150 \mu \mathrm{Ci}$ of $\left[{ }^{35} \mathrm{~S}\right]$ methionine (Radiochemical Centre, Amersham, England; $1,380 \mathrm{Ci} / \mathrm{mmol}$ ) between 20 and $25 \mathrm{~h}$ postinfection.

Subcellular fractionation of protoplasts. At the end of the incubation period, protoplasts were collected by centrifugation and stored frozen at $-80^{\circ} \mathrm{C}$. For subcellular fractionation, frozen protoplast samples were thawed and disrupted by homogenization for $5 \mathrm{~min}$ with a small potter with $0.5 \mathrm{ml}$ of homogenization buffer (HB), containing $50 \mathrm{mM}$ Tris-hydrochloride (pH 7.4), $10 \mathrm{mM} \mathrm{KCl,} 5 \mathrm{mM} \mathrm{MgCl}_{2}, 1 \mathrm{mM}$ EDTA, $60 \mathrm{mM} \beta$-mercaptoethanol, $1 \mathrm{mM}$ phenylmethylsulfonyl fluoride, $0.4 \mathrm{mM}$ methionine, and $10 \%$ (wt/vol) sucrose. Intact cells were removed by lowspeed centrifugation $\left(30 \mathrm{~s}, 500 \times g, 4^{\circ} \mathrm{C}\right)$. The homogenate was centrifuged for $30 \mathrm{~min}$ at $30,000 \times g$ and $4^{\circ} \mathrm{C}$ to give the $30,000 \times g$ supernatant. The $30,000 \times$ $g$ pellet was extracted with (per $2.5 \times 10^{6}$ protoplasts) $0.125 \mathrm{ml}$ of $\mathrm{HB}$ lacking $\mathrm{MgCl}_{2}$ to which $0.2 \%$ (wt/vol) digitonin had been added. Centrifugation of this suspension for $30 \mathrm{~min}$ at $30,000 \times g$ gave the $30,000 \times g$ pellet extract.

In vitro translation. Translation in an mRNAdependent rabbit reticulocyte lysate (a generous gift of H. R. B. Pelham, Department of Embryology, Carnegy Institution of Washington, Baltimore, Md.) was performed as described by Pelham (13). In all experiments the dithiothreitol concentration was $2 \mathrm{mM}$, and CPMV RNA was added at $60 \mu \mathrm{g} / \mathrm{ml}$. [ $\left.{ }^{35} \mathrm{~S}\right]$ methionine was used as the radioactive amino acid, and incubations were at $30^{\circ} \mathrm{C}$ for $1 \mathrm{~h}$.

Sodium dodecyl sulfate-polyacrylamide slab gel electrophoresis. Equal amounts of labeled proteins (as measured by acid-precipitable radioactivity) were mixed with 0.5 volume of a threefold-concentrated solution of sample buffer (final concentrations: $10 \mathrm{mM}$ Tris-hydrochloride [pH 8.0], $1 \mathrm{mM}$ EDTA, $10 \%$ [vol/vol] glycerol, $2 \%$ [wt/vol] sodium dodecyl sulfate [SDS], $5 \%$ [vol/vol] $\beta$-mercaptoethanol, and $0.001 \%$ [wt/vol] bromophenol blue). After heating samples for $3 \mathrm{~min}$ at $100^{\circ} \mathrm{C}$, they were analyzed in polyacrylamide gels containing $12.5 \%$ acrylamide with $0.09 \%$ bisacrylamide as previously described (12), using spacers of $4 \%$ acrylamide with $0.1 \%$ bisacrylamide. Molecular weight markers used were myosin $(210,000)$, Escherichia coli RNA nucleotidyltransferase $(165,000$ and 155,000$)$, $E$. coli $\beta$-D-galactosidase $(116,200)$, phosphorylase $b(100,000$ and 92,500$)$, bovine serum albumin $(68,000)$, ovalbumin $(46,000)$, carbonate dehydratase $(30,000)$, soybean trypsin inhibitor $(20,100)$, and $\alpha$-lactalbumin $(14,400)$. Gels were dried and autoradiographed with Kodak Royal X-Omat film.

Peptide mapping. Polypeptides, localized by autoradiography, were eluted from dried, unstained gels by incubating gel slices in small volumes of $30 \mathrm{mM}$ Tris-hydrochloride (pH 6.8) $-0.25 \mathrm{mM}$ EDTA-0.025\% sodium dodecyl sulfate for 16 to $64 \mathrm{~h}$ at $4^{\circ} \mathrm{C}$. The volume of the eluted protein samples was reduced four times by vacuum evaporation, and the sodium dodecyl sulfate concentration was raised to $0.5 \%$. Partial digestion with Staphylococcus aureus V8 protease (Miles Laboratories, Inc., Elkhart, Ind.) or chymotrypsin (Worthington Biochemicals Corp., Freehold, N.J.) was performed at $30^{\circ} \mathrm{C}$ for $30 \mathrm{~min}$ with various enzyme concentrations as indicated in the figure legends. Peptide patterns were compared in $17.5,20$, or $22.5 \%$ polyacrylamide gels containing $0.07,0.07$, or $0.06 \%$ bisacrylamide, respectively.

\section{RESULTS}

The 170K and 32K polypeptides produced in CPMV-infected protoplasts are virus coded. Infection of cowpea protoplasts with CPMV results in the synthesis of at least eight polypeptides, with estimated sizes of 170,110 , $87,84,68,37,30$, and 23 kilodaltons $(8 \mathrm{a}, 15)$, the $170 \mathrm{~K}$ and $30 \mathrm{~K}$ polypeptides being the first products synthesized (Rottier et al., J. Gen. Virol., in press). These polypeptides were predominantly found in the $30,000 \times g$ supernatant fraction of the protoplasts (Fig. 1, lane 6), with the exception of the $68 \mathrm{~K}$ polypeptide, which was only detected in the $30,000 \times g$ pellet fraction. The latter polypeptide is visible in lane 3 of Fig. 1 and has been indicated with 60 (recent estimates give a slightly different size for this polypeptide [formerly $68 \mathrm{~K}$, now $60 \mathrm{~K}$ ] as well as for the $30 \mathrm{~K}$ polypeptide [now $32 \mathrm{~K}$ ]). All of these polypeptides except for the (37K and 23K) coat proteins, were also synthesized in protoplasts inoculated with the purified B component (Fig. 1, lanes 2 and 7; reference 8a). Pelham (13) has shown that in the reticulocyte system the primary translation product of B RNA is a polypeptide of approximately 205 kilodaltons which is cleaved into two polypeptides of 170 and 32 kilodaltons. We confirmed this result except that our calculations indicated an apparent molecular weight of 200,000 for the largest polypeptide. The $170 \mathrm{~K}$ and $32 \mathrm{~K}$ polypeptides produced in vitro coelectrophoresed with the $170 \mathrm{~K}$ and $32 \mathrm{~K}$ polypeptides produced in protoplasts infected with complete virus or with B component alone (Fig. 1, cf. lanes 6,7 , and 8), suggesting that these polypeptides were identical. To verify this, the proteins were eluted from the gel and subjected to partial proteolytic digestion with V8 protease 


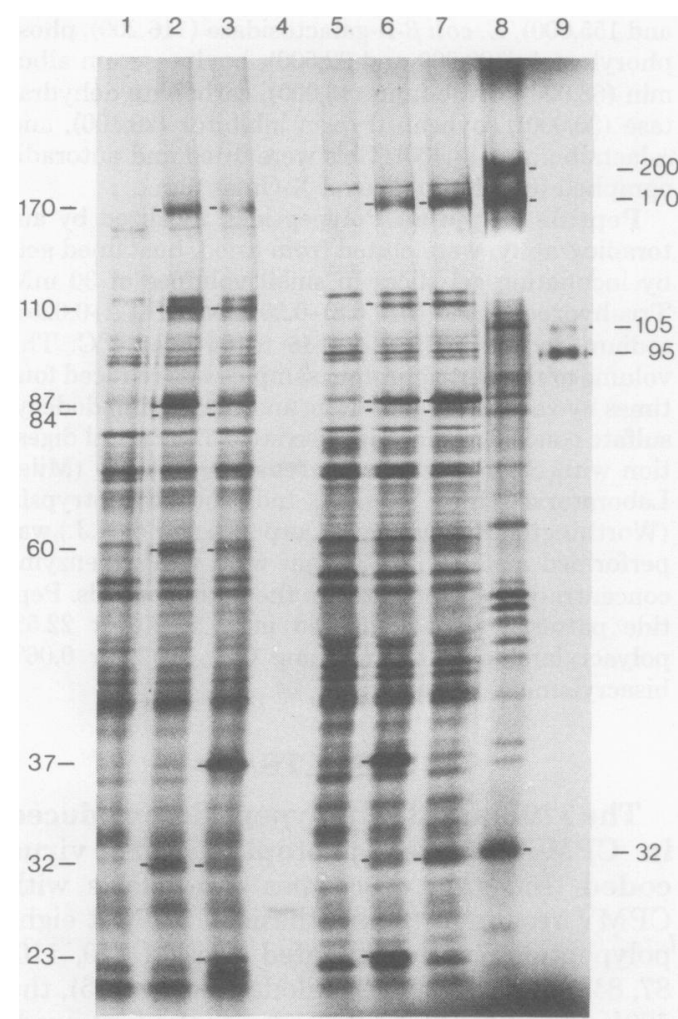

Fig. 1. Analysis of ${ }^{35} S$-proteins from cowpea protoplasts infected with CPMV components on a $12.5 \%$ sodium dodecyl sulfate-polyacrylamide gel. Samples of protoplasts were inoculated 20 to $25 \mathrm{~h}$ postinfection in the presence of $\left[{ }^{35} S\right]$ methionine (for details, see the text). Protoplasts were either mock infected (lanes 1 and 5), inoculated with purified B components (lanes 2 and 7), or inoculated with complete virus (M and $B$ components) (lanes 3 and 6). Lanes 1, 2, and 3 .contained the proteins extracted from the $30,000 \times g$ pellets; lanes 5,6 , and 7 contained the proteins from the $30,000 \times g$ supernatant fractions (for details, see the text). Lane 4 contained ${ }^{14} C$-methylated marker proteins (Radiochemical Centre), only visible in longer-exposed autoradiograms. Lanes 8 and 9 contained the translation products of $C P M V B$ and $M$ $R N A$, respectively, synthesized in the rabbit reticulocyte cell-free system. The numbers at the left refer to the molecular weights $\left(\times 10^{-3}\right)$ of the virus-induced polypeptides synthesized in the cowpea protoplast system; the numbers at the right refer to the molecular weights $\left(\times 10^{-3}\right)$ of the main products synthesized in the reticulocyte system. In the latter system M RNA was translated into two polypeptides, with molecular weights of 105,000 and 95,000, whereas the endogenous activity (no RNA added) of the reticulocyte lysate used was undetectable (data not shown).

from $S$. aureus or chymotrypsin. The digestion patterns of both the in vivo and the in vitro 170K polypeptides appeared to be identical and not significantly different from that of the $200 \mathrm{~K}$ in vitro polypeptide (Fig. 2). For instance, at the highest V8 protease concentration used $(0.75$ $\mathrm{mg} / \mathrm{ml}$ ), these three polypeptides had at least nine peptides in common. Protease V8 digestion of both 32K polypeptides also produced indistinguishable patterns, although the peptide bands became weaker at the higher protease concentrations used (Fig. 2). Cleavage with chymotrypsin (Fig. 2) provided additional evidence that these polypeptides were identical. However, the results shown in Fig. 2 did not decisively indicate whether the amino acid sequence of the $32 \mathrm{~K}$ polypeptide was present in the $200 \mathrm{~K}$ polypeptide and absent in both $170 \mathrm{~K}$ polypeptides, as would be expected from the results of Pelham (13). This was mainly due to the large size difference between the $32 \mathrm{~K}$ polypeptide and the other polypeptides, making a comparison by peptide mapping less suitable. Nevertheless, Fig. 2 shows conclusively that both the $170 \mathrm{~K}$ and the $32 \mathrm{~K}$ polypeptides produced in protoplasts infected with CPMV were coded by the B RNA of the virus.

Relationship between the 170K, 110K, and $87 \mathrm{~K}$ polypeptides. The $170 \mathrm{~K}$ and $32 \mathrm{~K}$ in vivo polypeptides together represent approximately $85 \%$ of the coding capacity of B RNA. This raises the question of whether the other (110K, 87K, 84K, and 60K) B-component-induced polypeptides are also virus coded and, if this is the case, by which mechanism they arise. To answer these questions we made peptide maps of all B-component-induced polypeptides, using $S$. aureus V8 protease at three different concentrations. The $170 \mathrm{~K}, 110 \mathrm{~K}$, and $87 \mathrm{~K}$ polypeptides were closely related, as illustrated by a strong resemblance between their peptide maps (Fig. 3A). The most important peptides demonstrating the relationship between these three polypeptides are indicated with dots in Fig. 3. For instance, at the highest protease concentration used (in Fig. 3A, lane c) these proteins produced at least eight common peptides. The 170K polypeptide digest contained several (at least five) peptides which were lacking in both the $110 \mathrm{~K}$ and the $87 \mathrm{~K}$ peptide maps. Compared with the $87 \mathrm{~K}$ polypeptide digest, the $110 \mathrm{~K}$ polypeptide digest contained only two obvious extra peptides, whereas the $87 \mathrm{~K}$ polypeptide pattern contained one small unique (possibly terminal) peptide. This close relationship was further supported by the peptide maps shown in Fig. 3B. In this experiment the digestion patterns of both proteins, after using $30 \mu \mathrm{g}$ of protease V8 per ml (Fig. 3B, cf. lane b), showed at least 15 peptides in common within a size range of 50 to 14 kilodaltons.

The striking similarities within their peptide patterns indicated that the $170 \mathrm{~K}, 110 \mathrm{~K}$, and $87 \mathrm{~K}$ 


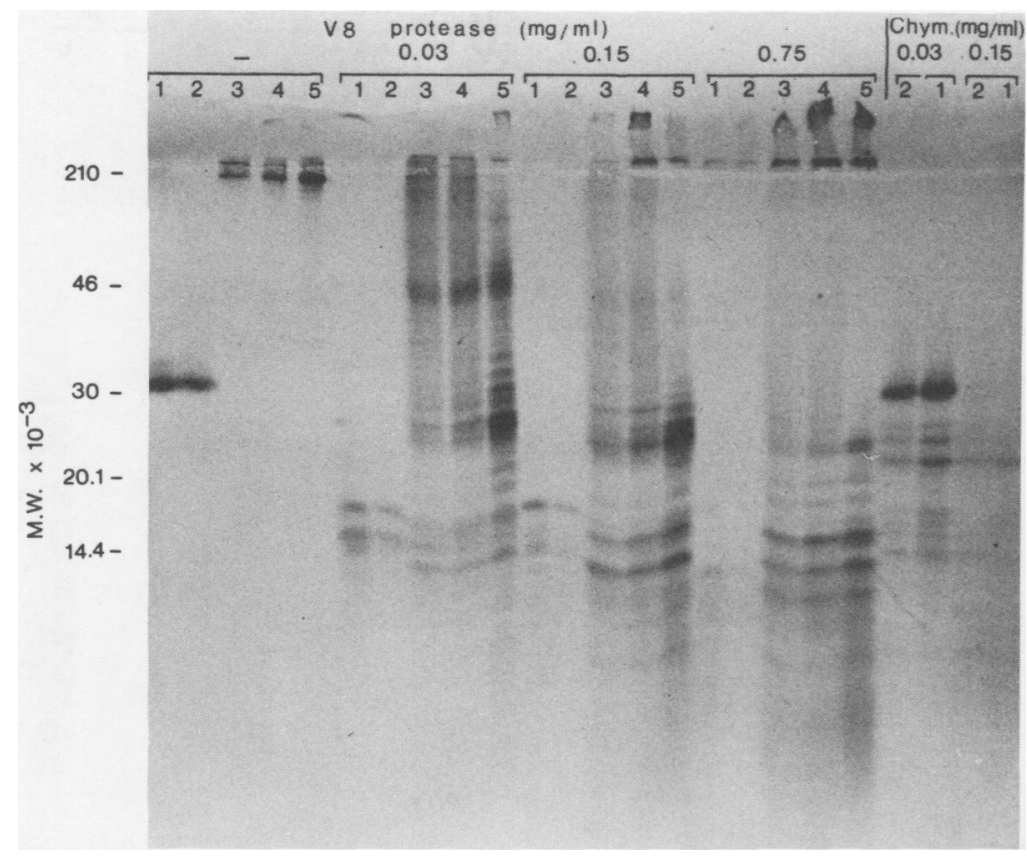

Fig. 2. Autoradiogram of the peptide maps of the in vitro B-RNA-coded 32K (ianes 1), 170K (lanes 4), and $200 K$ (lanes 3) polypeptides and the $32 K$ (lanes 2) and $170 K$ (lanes 5) polypeptides from CPMV-infected protoplasts. The [ ${ }^{35}$ S]methionine-labeled proteins were eluted from dried $12.5 \%$ acrylamide gels and digested with increasing amounts (indicated in the figure; -, no enzyme added) of $S$. aureus V8 protease or chymotrypsin (Chym.). Peptides generated by proteolysis were electrophoresed in a 22.5\% acrylamide gel which was subsequently dried and autoradiographed. The molecular weights (M.W.) indicated refer to the positions of myosin $(210,000)$, ovalbumin $(46,000)$, carbonate dehydratase $(30,000)$, soybean trypsin inhibitor $(20,100)$, and $\alpha$-lactalbumin $(14,400)$ in the gel.

polypeptides had a major part of their amino acid sequence in common, suggesting that the $110 \mathrm{~K}$ and $87 \mathrm{~K}$ polypeptides were derived from the 170K polypeptide by posttranslational processing steps.

Relationship between the $170 \mathrm{~K}, 84 \mathrm{~K}$, and $60 \mathrm{~K}$ polypeptides. At the highest V8 protease concentration used, the digestion pattern of the 170K polypeptide contained several peptides which were lacking in the $110 \mathrm{~K}$ and $87 \mathrm{~K}$ digests (Fig. 3A, lane c). Of these peptides the most pronounced (indicated with arrowheads in Fig. 3A) comigrated with the V8-derived peptides from the $84 \mathrm{~K}$ polypeptide. In addition, the peptide patterns of the $170 \mathrm{~K}$ and $84 \mathrm{~K}$ polypeptides shared at least two other characteristic peptides (of higher molecular weight) when less protease was used (Fig. 3A, lane b). The relationship between the $170 \mathrm{~K}$ and $84 \mathrm{~K}$ polypeptides was further underlined by the results shown in Fig. 4. The peptide patterns of the $170 \mathrm{~K}$ and $84 \mathrm{~K}$ proteins again showed the same (at least seven) comigrating peptides, suggesting that the complete amino acid sequence of the $84 \mathrm{~K}$ polypeptide was present in the $170 \mathrm{~K}$ protein. However, the relationship between the $60 \mathrm{~K}$ polypeptide and the other virus-specific polypeptides was less clear. This polypeptide had only one pronounced protease V8-derived peptide (size, approximately 16 kilodaltons) in common with both the $170 \mathrm{~K}$ and the $84 \mathrm{~K}$ proteins (Fig. 4). Five other peptides appeared to comigrate in the peptide patterns of $60 \mathrm{~K}$ and $84 \mathrm{~K}$, although they gave rise only to very faint bands. An extensive relationship between these two proteins was therefore less certain. Due to the relatively low yield of the $60 \mathrm{~K}$ protein from infected protoplasts, this remains a point in question.

\section{DISCUSSION}

It has been previously shown $(8 \mathrm{a}, 15$; Rottier et al., J. Gen. Virol., in press) that infection of cowpea protoplasts with CPMV induces the synthesis of at least eight virus-specific proteins, with apparent sizes of $170,110,87,84,60,37,32$, and 23 kilodaltons. The $37 \mathrm{~K}$ and $23 \mathrm{~K}$ proteins represent the capsid proteins. Upon inoculation of protoplasts with $B$ components alone, at least the $170 \mathrm{~K}, 110 \mathrm{~K}, 87 \mathrm{~K}, 84 \mathrm{~K}, 60 \mathrm{~K}$, and $32 \mathrm{~K}$ proteins are synthesized, but not the capsid proteins 


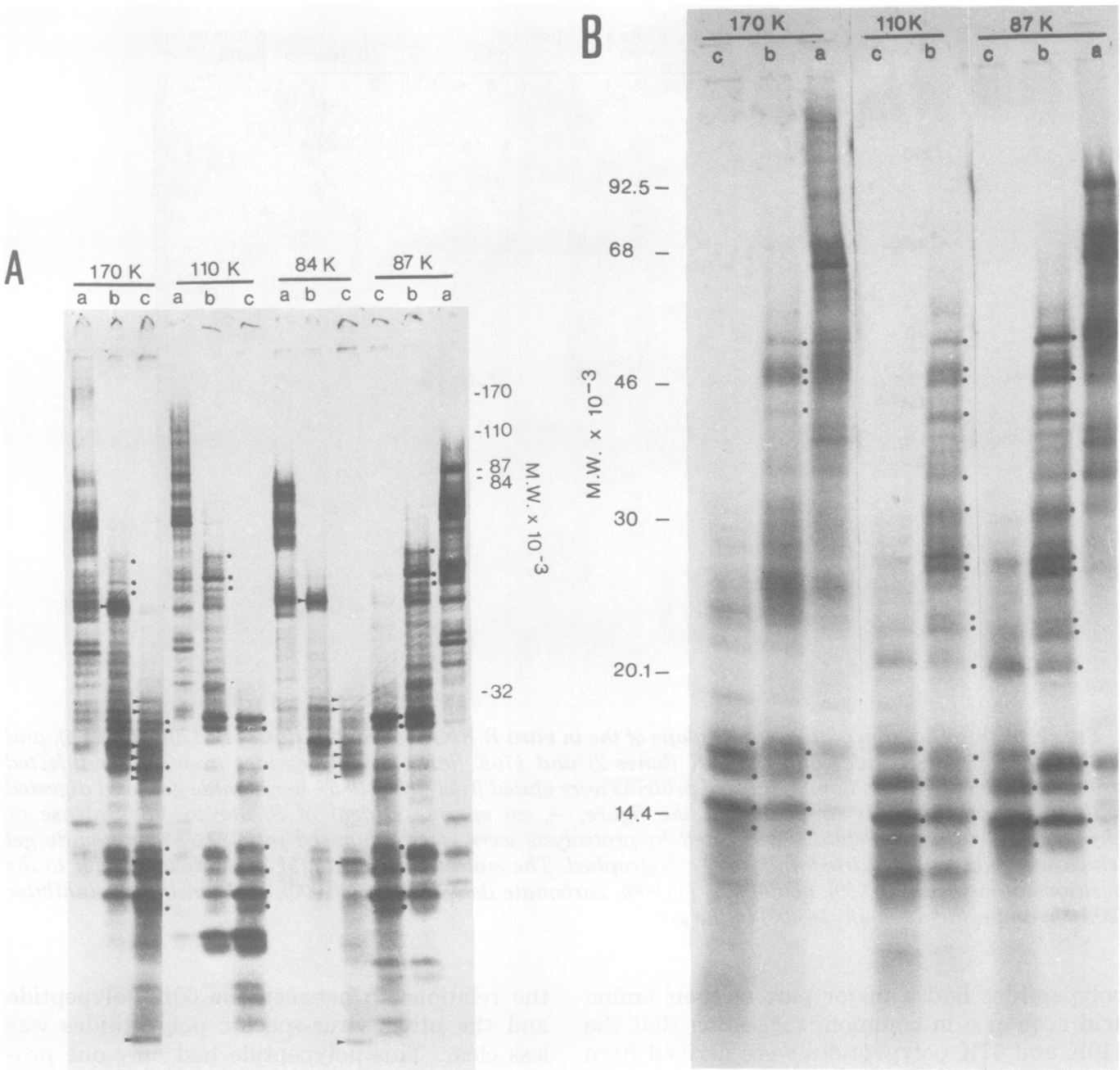

Fig. 3. Analysis of the peptide patterns obtained from the virus-specific $170 \mathrm{~K}, 110 \mathrm{~K}, 87 \mathrm{~K}$, and $84 \mathrm{~K}$ polypeptides from CPMV-infected protoplasts. Polypeptides were eluted from a dried 12.5\% acrylamide gel and incubated with $3(a), 30(b)$, or 150 (c) $\mu g$ of $V 8$ protease from $S$. aureus per ml (for details, see the text). The resulting peptides were analyzed in a $22.5 \%$ (A) or a $17.5 \%$ (B) acrylamide gel. Dots refer to proteasederived peptides demonstrating the relationship between the $170 \mathrm{~K}, 110 \mathrm{~K}$, and $87 \mathrm{~K}$ polypeptides. Peptides indicated with arrowheads demonstrate the relationship between the $170 \mathrm{~K}$ and $84 \mathrm{~K}$ polypeptides. M.W., Molecular weight.

(see Fig. 1 and reference $8 \mathrm{a}$ ).

By comparison of the peptide fingerprints of the $170 \mathrm{~K}$ and $32 \mathrm{~K}$ polypeptides translated in vitro from CPMV B RNA with those of the equal-sized, virus-specific polypeptides from infected cells, it has now been demonstrated that the latter polypeptides are actually virus coded. In addition, these results indicate that the translation of B RNA in the rabbit reticulocyte system, as described in detail by Pelham (13), correctly produces proteins as seen in vivo. In this in vitro system CPMV B RNA is translated into a polypeptide of approximately 200 kilodaltons which is then proteolytically cleaved to give the $170 \mathrm{~K}$ and $32 \mathrm{~K}$ polypeptides. A $200 \mathrm{~K}$ polypeptide has not yet been found in infected cells. In view of the correct translation in the reticulocyte system, it is reasonable to assume that the same cleavage from a $200 \mathrm{~K}$ primary precursor polypeptide also occurs in vivo. This remains to be verified, however.

By comparison of their proteolytic digestion patterns (using $S$. aureus V8 protease) on polyacrylamide gels, we have shown that the virusspecific $110 \mathrm{~K}, 87 \mathrm{~K}, 84 \mathrm{~K}$, and, possibly, $60 \mathrm{~K}$ polypeptides have amino acid sequences in common 


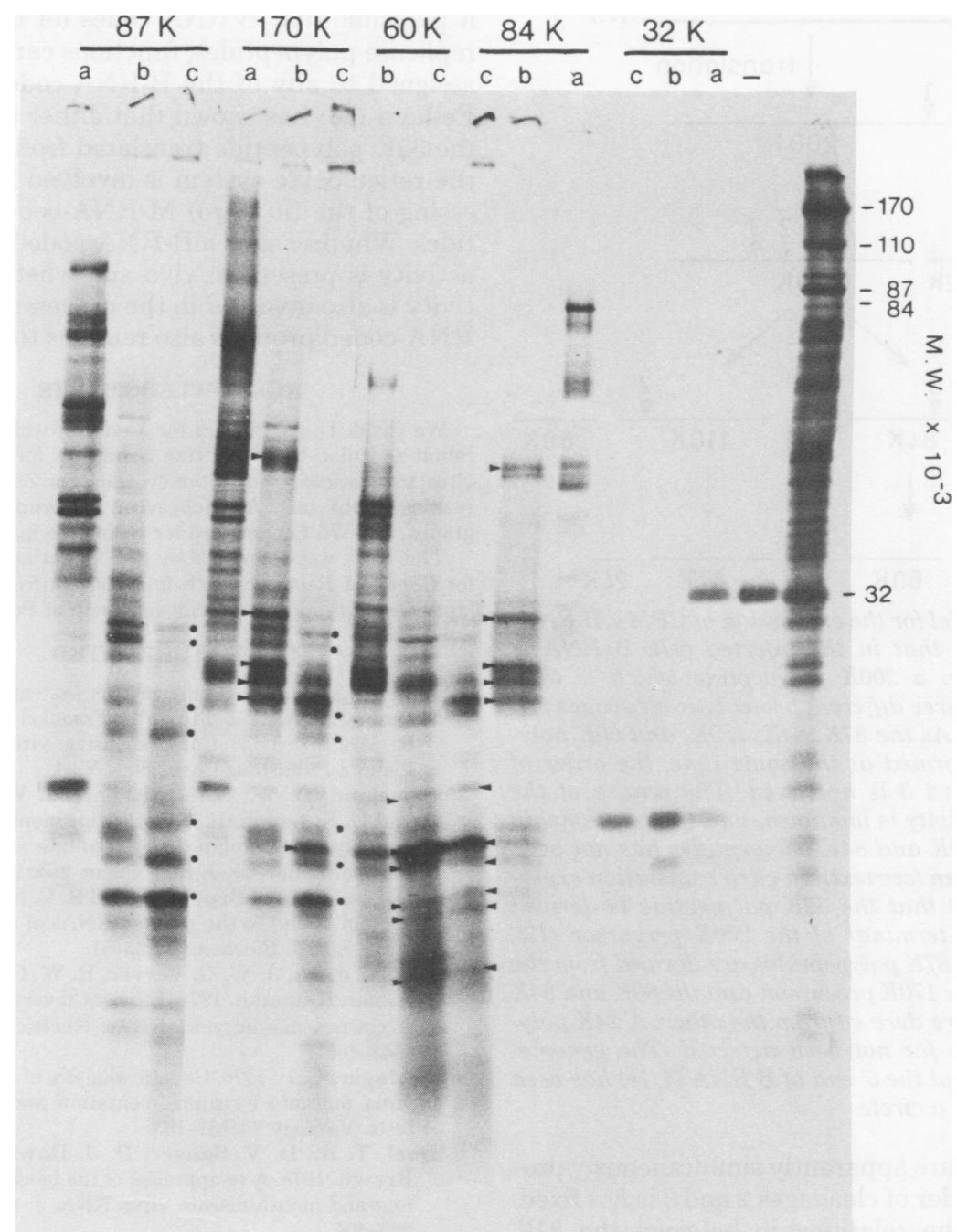

Fig. 4. Autoradiogram of the virus-specific $170 \mathrm{~K}, 87 \mathrm{~K}, 84 \mathrm{~K}, 60 \mathrm{~K}$, and $32 \mathrm{~K}$ polypeptides digested with different amounts of S. aureus V8 protease. Incubations were performed with $3(a), 30$ (b), or 150 (c) of protease per $\mathrm{ml}$ or without protease (-). The marker slot (right) contained the $30,000 \times \mathrm{g}$ supernatant proteins of protoplasts inoculated with CPMV B component. Peptides marked with arrowheads indicate the relationship between the $170 \mathrm{~K}, 84 \mathrm{~K}$, and $60 \mathrm{~K}$ polypeptides; peptides marked with dots indicate the relationship between the $170 \mathrm{~K}$ and $87 \mathrm{~K}$ polypeptides. M.W., Molecular weight.

with the $170 \mathrm{~K}$ polypeptide. Nearly all protease V8-derived peptides of the $87 \mathrm{~K}$ polypeptide could be recovered in both the $110 \mathrm{~K}$ and the 170K protease V8-peptide maps. This finding indicates that the $170 \mathrm{~K}$ polypeptide contains two different cleavage sites, which are used for the derivation of the $110 \mathrm{~K}$ and $87 \mathrm{~K}$ polypeptides. However, the $87 \mathrm{~K}$ and $84 \mathrm{~K}$ polypeptides have totally different peptide patterns. Although other mechanisms cannot be completely ruled out, all results fit the model for the expression of B RNA presented in Fig. 5. The model proposes that all B-component-specific polypep- tides (see Fig. 1, lanes 2 and 7) are cleaved from a single $200 \mathrm{~K}$ polyprotein by three successive cleavages. It has been assumed that the primary cleavages of the $200 \mathrm{~K}$ precursor to give $170 \mathrm{~K}$ and $32 \mathrm{~K}$ polypeptides as found in the rabbit reticulocyte system (13) also occurs in vivo. The fact that in infected cells the $170 \mathrm{~K}$ and $32 \mathrm{~K}$ polypeptides are the first detectable viral products is not inconsistent with this idea (Rottier et al., J. Gen. Virol., in press). The $200 \mathrm{~K}, 170 \mathrm{~K}$, $110 \mathrm{~K}$, and $84 \mathrm{~K}$ polypeptides are precursors, and the others $(87 \mathrm{~K}, 60 \mathrm{~K}$, and $32 \mathrm{~K}$ polypeptides) are end products. As the $110 \mathrm{~K}, 87 \mathrm{~K}, 84 \mathrm{~K}$, and $60 \mathrm{~K}$ 


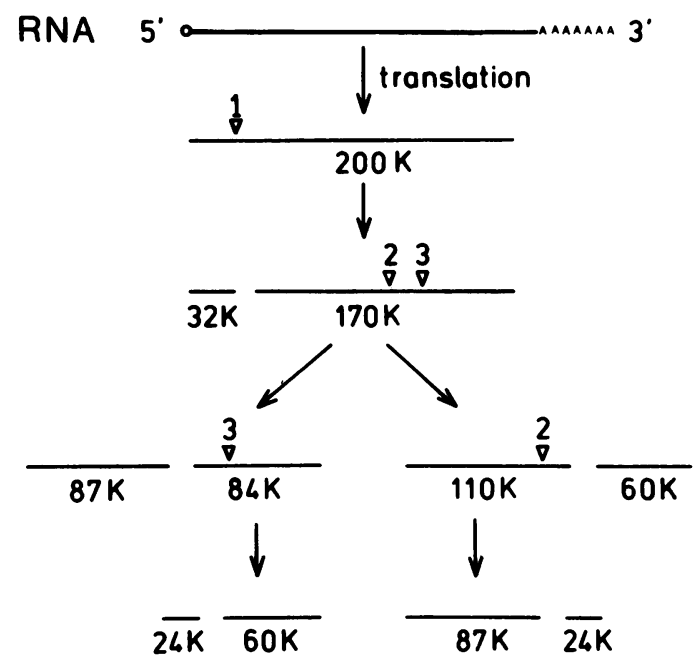

Fig. 5. Model for the expression of CPMV B RNA. It is proposed that in the infected cell, $B$ RNA is translated into a $200 \mathrm{~K}$ polypeptide which is then processed by three different proteolytic cleavages (indicated by $\nabla)$. As the $87 \mathrm{~K}, 84 \mathrm{~K}, 110 \mathrm{~K}$, and $60 \mathrm{~K}$ polypeptides are formed at the same time, the order of cleavages 2 and 3 is not fixed. The nature of the proteolytic activity is unknown, and the relationship between the $60 \mathrm{~K}$ and $84 \mathrm{~K}$ polypeptides has not been definitely proven (see text). In vitro translation exper. iments suggest that the $32 \mathrm{~K}$ polypeptide is derived from the $\mathrm{NH}_{2}$-terminal of the $200 \mathrm{~K}$ precursor (13). The $110 \mathrm{~K}$ and $87 \mathrm{~K}$ polypeptides are derived from the same end of the $170 \mathrm{~K}$ precursor, and the $60 \mathrm{~K}$ and $84 \mathrm{~K}$ polypeptides are derived from the other. A $24 K$ polypeptide has so far not been detected. The genomelinked protein at the 5 ' end of $B$ RNA $(3,16)$ has been indicated with a circle.

polypeptides are apparently simultaneously produced, the order of cleavages 2 and 3 is not fixed. To explain the relationship between the $84 \mathrm{~K}$ and $60 \mathrm{~K}$ polypeptides on the one hand and that between the $110 \mathrm{~K}$ and $87 \mathrm{~K}$ polypeptides on the other, as suggested by the model, the presence of a polypeptide of approximately 24 kilodaltons must be envisaged. Such a protein has not been found. This may be due, however, to either a rapid turnover, a lack of methionine residues (by which the radioactive label was introduced in the procedures adopted), or masking by an equal-sized host protein. Alternatively, it is possible that the $24 \mathrm{~K}$ polypeptide does not exist. This would be the case if the $110 \mathrm{~K}$ and $84 \mathrm{~K}$ polypeptides were not further cleaved, but were functional proteins. This would mean that the $170 \mathrm{~K}$ polypeptide is processed in two alternative ways, resulting in four different proteins $(110 \mathrm{~K}$, $87 \mathrm{~K}, 84 \mathrm{~K}$, and $60 \mathrm{~K}$ ), having distinct functions. Such a translation strategy has been proposed for foot-and-mouth disease virus RNA (6).

Although recent experiments (8a) have made it plausible that B RNA codes for one or more replicase polypeptides, functions can still not be assigned to any of the B-RNA-coded proteins. Pelham (13) has shown that either the 170K or the $32 \mathrm{~K}$ polypeptide translated from $\mathrm{B}$ RNA in the reticulocyte system is involved in the processing of the (in vitro) M-RNA-coded polypeptides. Whether such a B-RNA-coded proteolytic activity is present in vivo and whether this activity is also involved in the processing of the BRNA-coded proteins also remains to be verified.

\section{ACKNOWLEDGMENTS}

We thank Hugh Pelham for kindly providing samples of rabbit reticulocyte lysate, Han Schilthuis for help in the in vitro translations, John Stanley and Pim Zabel for critical reading of the text, Ab Hoogeveen for printing the photographs, and Wil Landeweerd for typing the manuscript.

This work was supported by the Netherlands Foundation for Chemical Research, with financial aid from the Netherlands Organization for the Advancement of Pure Research.

\section{LTTERATURE CITED}

1. Bruening, G. 1977. Plant covirus systems: two-component systems, p. 55-141. In H. Fraenkel-Conrat and R. R. Wagner (ed.), Comprehensive virology, vol. 11. Plenum Publishing Corp., New York.

2. Cleveland, D. W., S. G. Fischer, M. W. Kirschner, and U. K. Laemmli. 1977. Peptide mapping by limited proteolysis in sodium dodecyl sulfate and analysis by gel electrophoresis. J. Biol. Chem. 252:1102-1106.

3. Daubert, S. D., G. Bruening, and R. C. Najarian. 1978. Protein bound to the genome RNAs of cowpea mosaic virus. Eur. J. Biochem. 92:45-51.

4. Davies, J. W., J. W. G. Verver, R. W. Goldbach, and A. van Kammen. 1978. Efficient reverse transcription of cowpea mosaic virus RNAs. Nucleic Acids Res. 5: 4643-4661.

5. De Jager, C. P. 1976. Genetic analysis of cowpea mosaic virus mutants by supplementation and reassortment tests. Virology 70:151-163.

6. Doel, T. R., D. V. Sanger, D. J. Rowlands, and F. Brown. 1978. A re-appraisal of the biochemical map of foot-and-mouth disease virus RNA. J. Gen. Virol. 41: 395-404.

7. HI Manna, M. M., and G. Bruening. 1973. Polyadenylate sequences in the ribonucleic acids of cowpea mosaic virus. Virology 56:198-206.

8. Goldbach, R. W., P. Borst, J. E. Bollen-de Boer, and E. F. J. van Bruggen. 1978. The organization of ribosomal RNA genes in the mitochondrial DNA of Tetrahymena pyriformis strain ST. Biochim. Biophys. Acta 521:169-186.

8a.Goldbach, R., G. Rezelman, and A. van Kammen. 1980 . Independent replication and experssion of B-component RNA of cowpea mosaic virus. Nature (London) 286:297-300.

9. Hibi, T., G. Rezelman, and A. van Kammen. 1975. Infection of cowpea mesophyll protoplasts with cowpea mosaic virus. Virology 64:308-318.

10. Jaspars, E. M. J. 1974. Plant viruses with a multipartite genome. Adv. Virus Res. 19:37-149.

11. Klootwijk, J., I. Klein, P. Zabel, and A. van Kammen. 1977. Cowpea mosaic virus RNAs have neither $\mathbf{m}^{7} \mathrm{GpppN}$... nor mono-, di-, or triphosphates at their 5'-ends. Cell 11:73-82.

12. Laemmli, U. K. 1970 . Cleavage of structural proteins during the assembly of the head of the bacteriophage T4. Nature (London) 227:680-685.

13. Pelham, H. R. B. 1979. Synthesis and proteolytic proc- 
essing of cowpea mosaic virus proteins in reticulocyte lysates. Virology 96:463-477.

14. Reijnders, L., A. M. J. Aalbers, A. van Kammen, and R. W. J. Thuring. 1974. Molecular weights of plant viral RNAs determined by gel electrophoresis under denaturing conditions. Virology 60:515-521.

15. Rottier, P. J. M., G. Rezelman, and A. van Kammen. 1979. The inhibition of cowpea mosaic virus replication by actinomycin D. Virology 92:299-309.

16. Stanley, J., P. Rottier, J. W. Davies, P. Zabel, and A. van Kammen. 1978. A protein linked to the $5^{\prime}$ termini of both RNA components of the cowpea mosaic virus genome. Nucleic Acids Res. 5:4505-4522.

17. Van Kammen, A. 1967. Purification and properties of the components of cowpea mosaic virus. Virology 31: 633-642.

18. Van Kammen, A. 1968. The relationship between the components of cowpea mosaic virus. I. Two ribonucleoprotein particles necessary for the infectivity of CPMV. Virology 34:312-318.

19. Van Kammen, A. 1972. Plant viruses with a divided genome. Annu. Rev. Phytopathol. 10:125-150. 